\title{
Appendiceal Carcinoid Clinical TNM Finding v7
}

National Cancer Institute

\section{Source}

National Cancer Institute. Appendiceal Carcinoid Clinical TNM Finding v7. NCI Thesaurus.

Code $C 89937$.

A clinical finding about one or more characteristics of appendiceal carcinoid, following the rules of the TNM AJCC V7 classification system. Clinical assessment is based on medical history, physical examination, and imaging. Determination of elevated urinary 5-HIAA may indicate liver metastasis. (from AJCC 7th Ed.) 